\title{
BOOK REVIEW \\ INTEGRATING INDONESIAN MUSLIM INTELLECTUAL DISCOURSE INTO THE ISLAMIC WORLD
}

\author{
Carool Kersten, Islam in Indonesia: the Contest for Society, Ideas, and Values (Oxford, Universi- \\ ty of Oxford Press, 2015) PP. 376
}

It is commonly known that Muslims in Indonesia are distinguishably different from their fellow Muslims in other regions. It has been suggested that Europeans noticed these differences during colonial period as far back as Raffles and Van Leur (van Bruinessen I999). However, it is Geertz's study (I968) that confirmed this distinction after comparing Muslims in Indonesia directly with Moroccan Muslims. For him, it was clear that Indonesian Muslims are 'malleable, tentative, syncretistic, and, most significantly of all, multivoiced' (Geertz I968). It is syncretism, as profoundly influenced by Hindus and Buddhist ideas and traditions, which has constructed the perception of violent Islam in Indonesia. Therefore, despite the connection between Indonesian Muslims and the Middle East, which can be traced back to the $7^{\text {th }}$ century, the relationship between the two is likely to be unequal. More straightforwardly, Indonesian Muslims are perceived to be in the periphery of the Islamic world. To some extent, perceptions among Muslims in Indonesia is sometimes not helpful either, as many believe the Middle Eastern version of Islam is hard to be Indonesianized. The recently coined term of 'Islam Nusantara' basically illustrates the relative distance between the two.

It is interesting to see whether this kind of relationship remains unchanged. By looking at the way of communication and interaction across the globe, the global connection is unde- niably accelerating discourse among Muslims and Indonesians are no exception. However, in terms of intellectual contribution, there are still quite limited numbers of Indonesians that can incorporate into the world stage. In some books, a handful of these names can be found, but the figures are still not significant. It can be suggested that this is partly due to Indonesian demographic factors, which are not encouraging Indonesians to express their ideas globally. With potential readers in Indonesia surpassing other Muslim countries there is a strong temptation that the contestation of ideas is conducted only in Indonesia and among their fellow Muslims in the country. Thus, there is no need to internationalize these ideas and reach potential readers beyond Indonesia's borders.

However, does the distance of the Indonesian Muslim intellectuals with others matter or is there any other way to negotiate it? In many ways, this is what the book is trying to achieve by arguing that indeed Muslims in Indonesia are not completely isolated from the global Islamic dynamism. In fact by looking at the debates among Muslim intellectuals in this country, the writer shows how contestation of ideas resembles those of the renowned scholars across the globe discussing Islam's voluminous worldly aspects. It may be difficult to position these debates beyond borders; nevertheless, it is the duty of observers to contextualize the discussions in a universal context. 
As an observer trying to fulfill the responsibility to represent these debates, Carool Kersten is quite successful in mapping the recent discussions on Islam and its relevance to the context of Indonesian nation state building. The nation might declare itself a secular state in form, but the reactions of Muslims are one of the basic foundations that essentially have shaped the dynamics of 'Indonesian-ness' until recent years. To make it straightforward, Kersten suggests that there are three different generations of contemporary Indonesian Muslim intellectuals debating the position of Islam as a religion of the state and society as well as the philosophical interpretation of its function in the framework of the nation state. For him, it is the response toward the failure of Islamic political aspiration that becomes the basis of re-interpretation of Islam within the country. It is the reality that the state is not appreciative of the greater role of Islam in politics that has driven the inspiration of not pushing Islamic agendas into the policy. This is the position that was initiated by the first generation of post colonial scholars, represented by the prominent intellectuals such as Nurcholish Madjid.

By using a history of ideas approach, Kersten explores the transmission of Madjid's ideas to rethink the formal Islamic political agenda very seriously. However, the initiation of reinterpretation of Islamic political role is not solely developed from his jargon of 'Islam yes! Islamic party no!' Some prominent figures from both Nahdlatul Ulama (NU) and Muhammadiyah; such as Abdurrahman Wahid, Amien Rais, and Syafii Ma'arif, also play a role in guiding both organizations to be more acceptable to the nation state. This figure is also laying the basis for critical intellectual communities to thrive which then became the backdrop of the second generation as well as the vanguard of the third generation. However, other intellectual figures of the first generation of post-colonial intellectuals such as Dawam Rahardjo, Kuntowidjoyo, and
Muslim Abdurrahman are also influential in the rise of progressive ideas amongst the latter generation (p. 282). However, it is interesting that most of the progressive ideas thrived with those intellectuals rooted in the tradition of pesantren before continuing their education in secular institutions (p. 64). No wonder the book spends more time discussing those with this educational background.

Other than an exploration of ideas based on generations, Kersten also suggests that a small circle of discussion groups also played a major role in shaping the efforts of re-interpretation of Islam. By this, he mentions two different groups based in State Islamic University (UIN) Syarif Hidayatullah, Jakarta and UIN Sunan Kalijaga, Yogyakarta. From there two schools of thinking are mentioned which were known as Mazhab Ciputat and Yogyakarta (p. 42). From both, some prominent figures, such as Azyumardi Azra and Amin Abdullah were positioned on the map as senior representatives and deemed as the second generation intellectuals, alongside those who were active in NU and Muhammadiyah such as Said Aqil Siraj, Masdar F. Mas'udi, and Dien Syamsuddin. Kersten notes that this generation is quite distinctive in terms of introducing a new kind of ulama that conveys solid knowledge of Islam into the discussion of its role in Indonesian free (p. 65). However, it is the third generation that benefits from the dynamics of these mazhabs of thinking by embracing various themes faced by Muslim society. Under the banner of certain terminology of progressive ideas, Kersten captures the interpretation of how Islam and its adherents in an Indonesian context should embrace issues such as modernism, pluralism, secularism, and liberalism. It is this proposed map of ideas which finds its relevance as the younger generation connect themselves with their seniors in the first and second generations. It is clear that there is an intersection between educational tradition, organizational affiliation and 
also intellectual tradition inherited by the mazhabs that shape their ideas represented by figures such as Fauzan Saleh, Ulil Absar Abdalla, Ahmad Baso, to Ramadi from NU's tradition and Zuly Qodir to Ahmad Najib Burhani from Muhammadiyah.

What makes Kersten's work is distinctive is the way he articulates their narratives as inter-generational flowing ideas. The history of ideas is applicable in this context so that one intellectual's ideas can be traced to others. By this, it is evident that each generation cannot be separated from the process from which ideas are transferred. For example, the history of their study from primary and secondary schools to higher education plays a great role in this process. After the first generation had been inspired by the works of a variety of scholars, including non-Muslims, the second was gathered in the academic circles that preserved these ideas. In Jakarta, mazhab Ciputat is influential in sustaining the legacy of Nurcholish Madjid.

More than that, it is not only the discussion on their thoughts which is explored in this book but also their location of their ideas in the context of wider intellectual narratives in the Middle East. It is quite fascinating to envisage their ideas with critical narratives of Muhammad Abid al-Jabiri, Nasr Hamid Abu Zayd, Mohammed Arkoun, and Hassan Hanafi. So, ideas are not isolated, they are interconnected. For example, Kersten writes that 'Rumadi relies primarily on Mohammed Arkoun, while Baso prefers al-Jabiri' (p. 95). Not only that, but he also tries to connect them with ideas from outside the Muslim world such as the writings of Frithjof Schuon, Jose Casanova, and more recently Alfred Stepan.

However, as the discussion becomes the intellectual consumption of the educated young generation, there is a tendency that these debates are no longer for the commoner. As they tend to be more conservative, the two organizations that once were the source of a critical and open Muslim generation have also become more conservative. This tendency is also underlined in the book by exploring some figures that are against such debates, especially Adian Husaini. It seems that Kersten focuses on the intellectual response as the only reason why there is very few figures in this camp. The explanation of conservative tendency of NU and Muhammadiyah cannot be separated from the response to the fact their supporters are beyond the reach of the debates. One of the members of Muhammadiyah central board, at a meeting in London early May 20I6, explained that what is needed more are those who can give a sermon for members at the grass roots, and unfortunately, not many of the young intellectuals of Muhammadiyah can meet this immediate demand. It is also the same question that is raised in the discussion of Kersten's ideas before the publication at Exeter in October 20I4 that these debates are not representative of the whole picture of Muslims in Indonesia. It is a clear example of how ideas are not always mirrored the public's main interest as the reactionary, and conservative visions tend to have more popular support. One of the reasons is their enthusiastic and widespread activists' ability to reach the masses (p. 282).

It seems that the writer gives less attention to those who are critical, categorized as reactionary, to these debates. This tendency can be traced to his position that is quite negative to the opponents by using the term 'blind' (p. 284) rather than another expression that is more neutral. This problematic position is quite clear as a deeper exploration of the link between the first generation of conservative proponents, and the later generation is quite absent. For example, it is true that DDII established by Muhammad Natsir, and also Imaduddin Abdulrahim played a great role in the development of tarbiyah movement. However, the link between the two and Muslim Brotherhood is not clearly defined. Abdulrahim's training was clearly influential in generating pious and devoted young Muslims, but the story of how ideas from Brotherhood's al-Banna transferred into the network is far more 
complex than simply solely originated from the training in Salman Mosque.

Nevertheless, despite these 'minor' problems, this book still offers a countless contribution into the study of Muslim in Indonesia. It is enjoyable to see that Muslim intellectuals in Indonesia are not far from the debates among intellectuals in the global Islamic world. It is proof that the presumption of periphery and detachment is not always the case for Indonesian Muslims.

SYAHRUL HIDAYAT

lecturer at the Department of Political Science, Universitas Indonesia and is currently an Honorary Research Fellow at the Institute of Arab and Islamic Studies, University of Exeter, UK.

\section{REFERENCES}

van Bruinessen, Martin (1999)"Global and local in Indonesian Islam", Southeast Asian Studies (Kyoto) vol. 37, no.2, pp. 46-63.

Geertz, Clifford (1968) Islam Observed: Religious Development in Morocco and Indonesia, Yale, Yale University Press. 